\title{
Wetland loss under the impact of agricultural development in the Sanjiang Plain, NE China
}

\author{
Jieyu Zhang $\cdot$ Keming Ma $\cdot$ Bojie Fu
}

Received: 15 September 2008 / Accepted: 13 May 2009 / Published online: 28 May 2009

(C) Springer Science + Business Media B.V. 2009

\begin{abstract}
Wetland loss has been the major environmental problem in Sanjiang Plain, NE China in recent years because of the dramatic agricultural development. We determined the spatial associations of the wetland loss rates in an $11,000-\mathrm{km}^{2}$ study area for two intervals of period 1 (1975-1989) and period 2 (1989-2004) spanning 30 years by using geographic information systems. The landscape of this area was simple with five categories, composed of ten types, and including three natural wetland types-open water, marsh, and wet meadow. Extensive agriculture was the principal cultivation form in terms of large size farm units in the area. Agriculture has become the principal land use category replacing natural wetlands over the 30 -year period. It has changed the whole landscape of the region and the landscape pattern, causing wetland loss and fragmentation. The wetland loss rate of the area was very differ-
\end{abstract}

J. Zhang $(\varangle) \cdot$ K. Ma · B. Fu

State Key Laboratory of Urban and Regional Ecology, Research Centre for Eco-environmental Sciences, Chinese Academy of Sciences, Beijing, 100085, China e-mail: zhangjieyu@hotmail.com

K. Ma

e-mail:mkm@rcees.ac.cn

J. Zhang

Graduate School of the Chinese Academy of Sciences, Beijing, 100049, China ent between the two intervals, while wetland loss was not uniform throughout the region and was influenced by the landscape characteristics, such as topography, geomorphology, and the location of the wetlands in the watershed. Despite the remarkable land use changes, the wetlands distribution in the landscapes was similar compared to their original pattern. These results indicated that agricultural development affected the areas more than the distribution pattern of the wetlands in this region.

Keywords Wetland loss • Extensive agriculture • Land use/cover change $\cdot$ Landscape pattern . Sanjiang Plain

\section{Introduction}

It has been noted that wetlands have the highest biodiversity of any landscape unit and have various important ecological functions (Mitsch and Gosselink 1993; Gopal and Junk 2001); their loss is of particular concern. Recently, wetlands worldwide have been among the fastest of any ecosystem type to show loss rates (Balmford et al. 2002). Unfortunately, precisely complete wetland loss data cannot be acquired because of the different definitions and techniques employed by the various assessments. In a generalized overview, the OECD (1996) estimates that the world may 
have lost $50 \%$ of its wetlands since 1900 , and land conversion for agriculture is the principal cause.

Increasing human land use has put wetlands at risk. Once thought to be wastelands, wetlands have been extensively drained for economic development. Direct land conversion for agricultural drainage, forestry, as well as urban construction has caused the destruction and degradation of wetlands (Yi et al. 1994; Spaling 1995; Mensing et al. 1998). For example, irrigation ditching can increase contamination of wetlands receiving irrigation drainage water, particularly where soil is alkaline or contains selenium or other heavy metals (Walters and Shrubsole 2003). Agricultural pesticides entering wetlands via runoff, as well as through atmospheric deposition, may be accumulated in fish and other aquatic organisms (Kennish et al. 1992).

According to the first wetland resource survey from 1996 to 2003 at the national level, China had 38 million hectares of wetland area (excluding the paddy fields), where 36 million hectares were natural at the end of 1995 (State Forestry Administration of China 2004). Despite the global warming trend, the loss and degradation of Chinese wetlands still took place dramatically in the past several decades under the high pressure of large population and economic development. Even though the statistical data of the original wetland area is lacking for the whole country at present, the data from recent researches on the Jianghan Plain (e.g., Wang and Wu 2004), the Sanjiang Plain (e.g., Liu et al. 2004), and the eastern coastal wetlands (e.g., Xiao and Li 2001) have also shown a large amount and high rate of wetland loss in the main wetland-rich regions of China.

Agricultural development, frequently the dominant human activities in floodplains and other wetland-rich areas, is a major cause of natural wetlands loss. The various agricultural activities, from drainage and irrigation at the local scale to exploitation and land conversion at the regional scale, have directly or indirectly altered the characteristics of regional environments and resulted in the loss and degradation of natural wetlands. While the agricultural activities are unlikely to be halted in the near future as anthropogenic disturbance, global water scarcity, and climate change would further impact on the remaining wetlands.
The objectives of the study are to examine land use and landscape pattern changes with an emphasis on wetland loss and to identify how the wetland distribution change is affected by the land use/cover changes along the vertical and horizontal gradients in space.

\section{Study area}

The Sanjiang Plain is situated in the northeast boarder part of the Heilongjiang Province in NE China. The most common landscape types are wetland and cultivated land, accounting for 0.9 and 4 million hectares, respectively, as about $27 \%$ and $30 \%$ of the provincial wetland and cultivated land, respectively. The wetlands in the Sanjiang Plain are world-renowned for hosting many rare, large-sized water birds; several most notable ones are globally threatened cranes, such as the Oriental stork (Ciconia boyciana), white-naped crane (Grus vipio), and red-crowned crane (G. japonensis). Agricultural activities, especially reclamation, have been considered the major threats to the wetlands of Sanjiang Plain in the past decades and the area of the cultivated land and its grain production have been developed at the cost of wetland loss (Wang et al. 2006). The cultivated lands in Sanjiang Plain are also well-known for producing large quantity and high quality of beans and rice in recent decades in China.

The study area, Jiansanjiang $\left(46^{\circ} 49^{\prime} 42^{\prime \prime}-48^{\circ} 13^{\prime}\right.$ $58^{\prime \prime} \mathrm{N}, 132^{\circ} 31^{\prime} 26^{\prime \prime}-134^{\circ} 22^{\prime} 26^{\prime \prime} \mathrm{E}$ ), a Chinese meaning "to exploit the Sanjiang Plain," belongs to the General Farming Bureau of the Heilongjiang Province, located in the northeastern interior of Sanjiang Plain (Fig. 1). The area of this region covering slightly over $11,000 \mathrm{~km}^{2}$ is consisted of 15 large farms. This region is remote from urban areas, and the major human activities are mostly related to agriculture, such as ditching, cultivating, fertilizing, and harvesting. The Jiansanjiang Farming District was selected because of its importance to the commercial production of agricultural products and because of the high degree of land conversion experienced, as well as the valuable remaining wetland remnants that exist within the context of the rural landscapes. There are one national wetland reserve, Honghe National 
Fig. 1 The location map of the study area

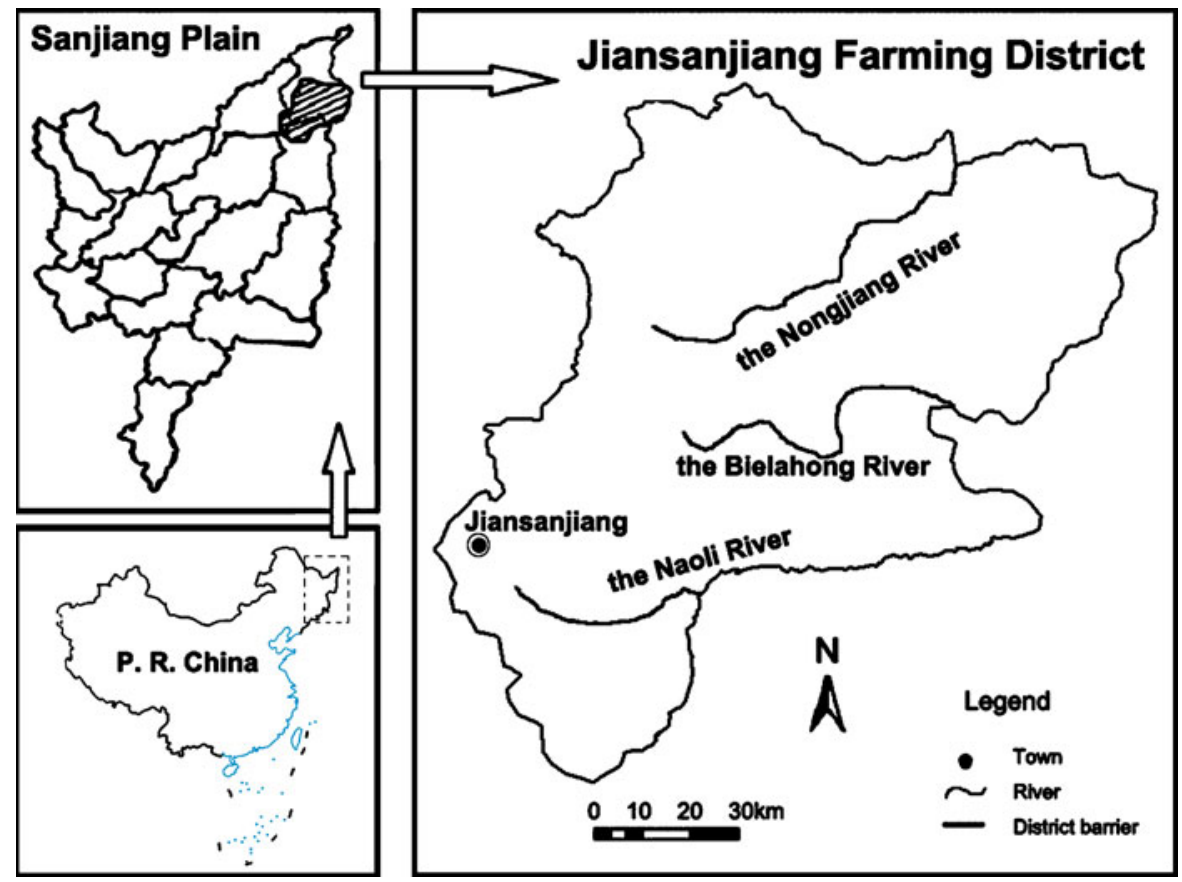

Wetland Natural Reserve, which was designated as a Ramsar site (the Convention on Wetlands, signed in Ramsar, Iran, in 1971, is an intergovernmental treaty which provides the framework for national action and international cooperation for the conservation and wise use of wetlands and their resources), and four provincial wetland reserves that are less disturbed by human activity and relatively pristine habitats to support the special wetland flora and fauna of the region.

\section{Methods}

Data acquisition

The data used in this study were extracted from three cloud-free Landsat Thematic Mapper (TM) images produced on June 15, 1975, June 23, 1989, and June 4, 2004 gathered from the China Remote Sensing Satellite Ground Station. Other data, including the topographical map $(1: 50,000)$ and the digital elevation model (DEM) image $(1: 50,000)$, were found from the National Geomatics Center of China. The river and channel system map of
Jiansanjiang $(1: 10,000)$ was digitized from the corresponding hardcopy map produced by Jiansanjiang Water Conservancy Bureau. All images were imported into the image-processing software ERDAS IMAGINE8.5 (ERDAS, Atlanta, GA, USA) and geocorrected into a coordinate system Transverse Mercator, D_Krasovsky_1940 by the selected 20 ground control points visible. According to the former studies of Sanjiang Plain (e.g., Liu et al. 2004) and our fieldwork in 2004, a landscape classification of ten landscape types, which were divided into five landscape categories, was established. Visual interpretation was employed in the classification of ArcGIS 8.0 and better precision of manual interpretation. The data were calibrated by further fieldwork to achieve better precision.

The ten landscape types included three natural wetland types (open water [OPW], marsh [MAR], wet meadow [WMD]), grassland (GRS), woodland (WDL), paddy field (PAD), dry cropland (DRY), main channel and ditch (CAN), settlement and associated areas (STT), and main road (MRD). The five landscape categories were natural wetland (WET), grassland (GRS), woodland (WDL), agricultural land (AGR), and built-up areas (BLD) (Table 1). 
Table 1 Landscape classification system

\begin{tabular}{ll}
\hline Landscape category & Landscape type \\
\hline 1. Natural wetlands(WET) & Open water (OPW) \\
& Marsh (MAR) \\
& Wet meadow (WMD) \\
& Grassland (GRS) \\
2. Grassland(GRS) & Woodland (WDL) \\
3. Woodland(WDL) & Paddy field (PAD) \\
4. Agricultural land(AGR) & Dry cropland (DRY) \\
& Main channel and ditch \\
& (CAN) \\
5. Built-up area (BLD) & Settlement and associated \\
& areas (STT) \\
& Main road (MRD) \\
\hline
\end{tabular}

Data analysis

\section{Changes of land area and rate}

According to the purpose of this study, period 1 was defined as the years between 1975 and 1989, whereas period 2 spanned 1989 to 2004. Two indices were calculated to compare the land use/cover changes between period 1 and period 2 and among landscape categories. Annual changes in area of each landscape category (annual land change area [ALCA]) quantified the change areas and the annual change rate of landscape category (annual land change rate [ALCR]) reflected the change rates, as described by:

$$
\begin{aligned}
& \mathrm{ALCA}=\left(U_{\mathrm{b}}-U_{\mathrm{a}}\right) \times \frac{1}{T}, \\
& \mathrm{ALCR}=\frac{U_{\mathrm{b}}-U_{\mathrm{a}}}{U_{\mathrm{a}}} \times \frac{1}{T} \times 100 \%
\end{aligned}
$$

where $U_{\mathrm{a}}$ and $U_{\mathrm{b}}$ represent the amount of the landscape category and type changed, respectively, at the beginning and the end of the study period and $T$ is the number of years in the study period.

\section{Landscape pattern metrics}

The extracted spatial and temporal data of the five landscape categories were then used to analyze landscape changes and patterns for each period.

Fig. 2 The classification maps in the 3 years
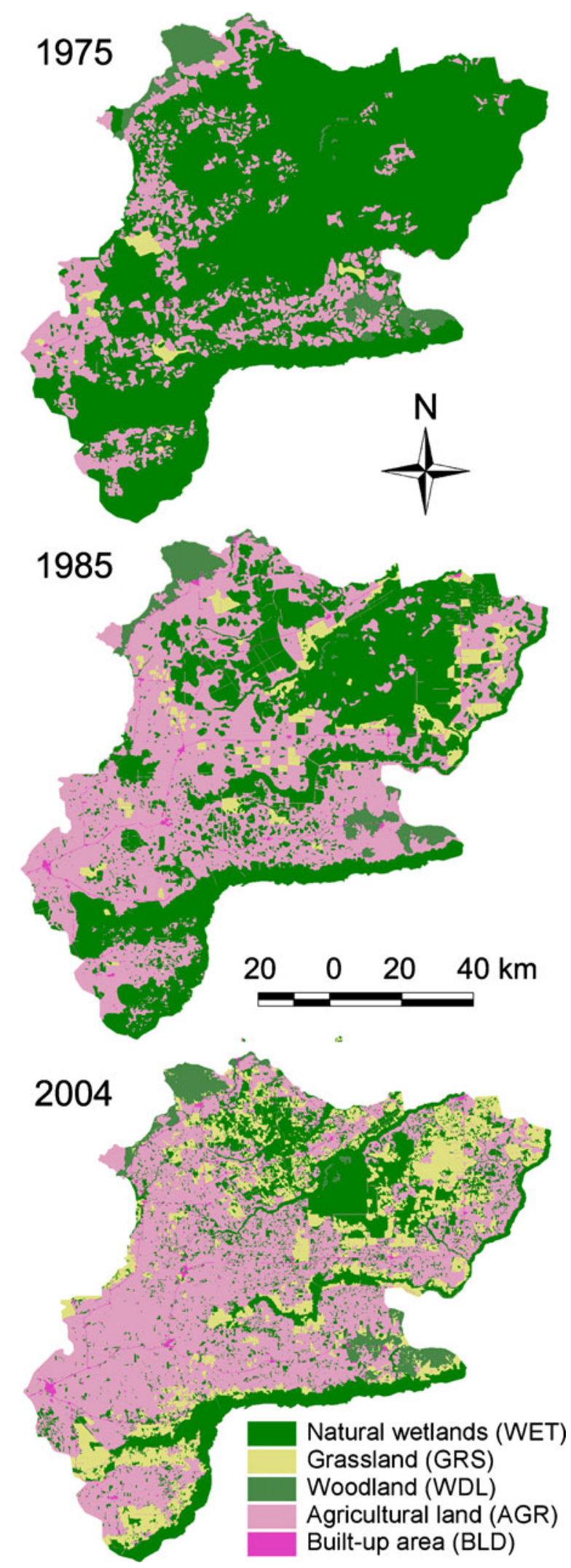
Choices for appropriate landscape pattern metrics are mainly dependent upon the scales of the analysis and the objectives of the study (Turner and Gardner 1991; Forman 1995; Turner et al. 2001). Mean patch size (MPS), number of patches (NumP), Shannon's diversity index (SDI), Shannon's evenness index (SEI), and class area (CA) were chosen to assess the landscape pattern. MPS is defined as the average patch size, NumP is defined as the count of patches, and CA is defined as the sum of areas of all patches belonging to a given class. SDI and SEI are only available at the landscape level. SDI is a measure of relative patch diversity and is equal to 0 when there is only one patch in the landscape and increases as the number of patch types or proportional distribution of patch types increases. SEI is a measure of patch distribution and abundance and is equal to 0 when the observed patch distribution is low and approaches 1 when the distribution of patch types becomes more even. All the spatial and temporal analyses and data development were performed using ArcView 3.2 and Patch Analyst 3.2 (Elkie et al. 1999).

\section{Wetlands distribution analysis}

Structural properties of wetland landscapes not only include the number (or total volume), size (or volume), and shape of wetland patches, but also the geographical distribution of different wetland types within the landscape unit. To determine how wetlands are distributed within the landscape and how land use changed the wetland distribution over time, the proportion of the wetland types was calculated along the elevation gradient and the river buffer gradient.

The DEM and the three classification maps were then overlaid, respectively, to acquire the wetland distribution pattern along the elevation. The probability of wetlands presented at an elevation of $h$ meters is described by:

Probability of wetlands presented at an elevation of $h$ meters $=\frac{\text { the wetlands area at } h \text { meters }}{\text { the total area at } h \text { meters }} \times 100$.

The proportion of wetlands distributed at $h$ meters is described by:

Proportion of wetlands distributed at $h$ meters $=\frac{\text { the wetlands area at } h \text { meters }}{\text { the total area of wetlands }} \times 100$.

The distribution of wetlands along the river buffer gradient was the proportion of wetlands within the river buffers over a distance of 300 to $5,000 \mathrm{~m}$ away from the river. The proportion of wetland area to the area of river buffer, $i$, is described by:

Proportion of wetland area to the area of river buffer, $i=\frac{\text { the wetlands area in the river buffer, } i}{\text { the total area of the river buffer, } i} \times 100$.

The cumulative proportion of wetlands within the river buffer, $i$, is described by:

Cumulative proportion of wetlands in the river buffer, $i=\frac{\text { the wetlands area in the river buffer, } i}{\text { the total area of wetlands }} \times 100$. 


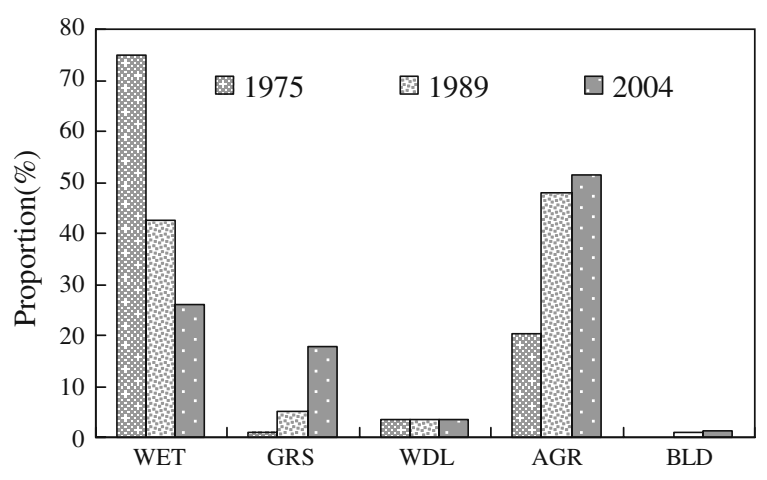

Fig. 3 Proportion of each landscape category in the 3 years. WET natural wetlands, GRS grassland, WDL woodland, $A G R$ agricultural land, $B L D$ built-up area

\section{Results}

Land use change and wetland loss

Landscape category classification maps for the 1975, 1989, and 2004 time periods can be found in Fig. 2. In addition, Fig. 3 shows the amount of changes in each landscape type as percent area, corresponding to the spatial areas depicted in the maps in Fig. 2. Before the 1980s, wetlands were the dominant landscape types, whereas, nowadays, the landscape of this region is characterized as agricultural fields dissected by a network of canals and ditches with a mosaic of wetlands and grasslands. Only natural wetlands gradually declined in proportion over the two periods. In contrast, grassland, agriculture, and built-up area showed an increase in their proportion and woodland kept stable.

During period 1 (1975-1989), natural wetlands decreased by approximately half (from $75.06 \%$ to $42.49 \%$ ); however, grassland quadrupled in
Table 3 Landscape pattern metrics of types in 1975, 1989, and 2004

\begin{tabular}{lllll}
\hline & MPS (ha) & NumP & SDI & SEI \\
\hline 1975 & 408.1 & 2,639 & 1.36 & 0.62 \\
1989 & 222.8 & 4,834 & 1.57 & 0.68 \\
2004 & 149.0 & 7,231 & 1.83 & 0.79 \\
\hline
\end{tabular}

area $(1.11 \%$ to $4.99 \%)$ and agriculture doubled (20.18\% to $47.93 \%)$. During period 2 (1989-2004), agricultural land increased slightly (by $3.38 \%$ ), representing the predominant landscape category in the region $(51.53 \%)$, while wetlands still decreased by about $16 \%$ (42.49\% to $26.06 \%$ ) and grassland almost tripled in area $(4.99 \%$ to $17.92 \%$ ).

Table 2 shows the annual changes of the amount and rate of different landscape categories. The absolute value of ALCA was less in period 2 than that in period 1 for wetland, agriculture, and built-up areas, which means that the areas of these three landscape categories changed much more in period 1 than that in period 2. However, as with the case of grassland, the area change was much larger in period 2 than that in period 1, whereas for woodland, there was no significant change. ALCR indicated that the built-up areas changed acutely in period 1 with a relatively smaller change in grassland in both periods. Wetland loss was slowed down from $257.77 \mathrm{~km}^{2} \cdot \mathrm{year}^{-1}$ in period 1 to $118.54 \mathrm{~km}^{2} \cdot$ year $^{-1}$ in period 1 shown by ALCA and from $3.14 \% \cdot$ year $^{-1}$ in period 1 to $2.58 \% \cdot$ year $^{-1}$ in period 2 shown by ALCR as well.

In general, the landscape pattern changed greatly (Table 3). MPS decreased sharply in 1989 (222.8 ha) from 1975 (408.1 ha), then decreased continuously (149.0 ha) by 2004 . NumP showed the opposite trend and increased from 2,639 in 1975 to 4,834 in 1989 , compared with that of 7,231
Table 2 Annual change of land areas (ALCA) and rate $(\mathrm{ALCR})$ of the landscape categories during period 1 (1975-1989) and period 2 (1989-2004)

\begin{tabular}{lccccc}
\hline Landscape category & Period 1 & & Period 2 & \\
\cline { 2 - 3 } \cline { 5 - 6 } & ALCA $\left(\mathrm{km}^{2}\right)$ & ALCR $(\%)$ & & ALCA $\left(\mathrm{km}^{2}\right)$ & ALCR $(\%)$ \\
\hline Natural wetlands (WET) & -257.77 & -3.14 & & -118.54 & -2.58 \\
Grassland (GRS) & 29.91 & 25.46 & & 91.06 & 17.10 \\
Woodland (WDL) & -0.35 & -0.09 & & -0.34 & -0.09 \\
Agriculture (AGR) & 220.05 & 10.79 & & 26.03 & 0.51 \\
Built-up area (BLD) & 7.16 & 130.33 & & 1.24 & 1.17 \\
\hline
\end{tabular}


Table 4 Landscape pattern metrics of the wetland types in 1975, 1989, and 2004

\begin{tabular}{|c|c|c|c|c|c|c|c|c|c|}
\hline & \multicolumn{3}{|c|}{ CA $\left(10^{4}\right.$ ha $)$} & \multicolumn{3}{|c|}{ MPS (ha) } & \multicolumn{3}{|c|}{ NumP } \\
\hline & 1975 & 1989 & 2004 & 1975 & 1989 & 2004 & 1975 & 1989 & 2004 \\
\hline Open water (OPW) & 6.63 & 5.22 & 2.68 & 44.1 & 38.1 & 37.8 & 1,504 & 1372 & 709 \\
\hline Marsh (MAR) & 24.9 & 17 & 8.69 & 496.0 & 234.1 & 529.6 & 502 & 726 & 164 \\
\hline Wet Meadow (WMD) & 50.57 & 23.79 & 16.87 & 2491.1 & 343.3 & 75.5 & 203 & 693 & 2235 \\
\hline
\end{tabular}

in 2004. The SDI and SEI both increased over the years.

\section{Wetlands fragmentation}

Three types of landscape were found in the wetlands in the region: OPW, MAR, and WMD, each of which changed variously. The landscape changes of the three wetland types in the region between years are shown in Table 4. Despite the differences, the CA of all the three types decreased by about $67 \%$ during the years. However, MPS and NumP varied amongst the three types. MPS of OPW decreased slightly (from 44.1 ha in 1975 to 38.1 ha in 1989 and to 37.8 ha in 2004) and WMD shrunk greatly (from 2,491.1 ha in 1975 to 343.3 ha in 1989 and to 75.5 ha in 2004), while MAR decreased and then increased (from 496.0 ha in 1975 to 234.1 ha in 1989 and to 529.6 ha in 2004). NumP for OPW decreased over time (from 1,504 in 1975 to 1,372 in 1989 and to 709 in 2004), whereas WMD increased (from 203 in 1975 to 693 in 1989 and to 2,235 in 2004). The MAR increased at first and then decreased (from 502 in 1975 to 726 in 1989 and to 164 in 2004).

Distribution change of wetlands in landscape

According to the DEM image, the elevation of the whole region ranges from $40 \mathrm{~m}$ to about $400 \mathrm{~m}$; however, the elevation of the landscape frequently fell into a range of 40 and $80 \mathrm{~m}$, representing about $95 \%$ of the regional area. The wetlands almost occurred within 40-60 m, and the probability of wetlands declined only at higher elevation (Fig. 4a). Under $60 \mathrm{~m}$, the probability of wetlands presented became smaller at the same elevation from 1975 through 1989 to 2004, whereas above $60 \mathrm{~m}$, the probability of wetland presented at the same elevation was in 1975 greater than in 2004 greater than in 1989, which maybe the reason of the sharp decrease of seasonal wetlands at higher elevation in 1989 lack of precipitation.

A similar feature of statistically normal distribution along the elevation gradient with the peak value at about the elevation of $55 \mathrm{~m}$ was observed in wetlands in the 3 years (Fig. 4b).

The proportions of the wetlands along river buffers differed in the 3 years but all of them expressing a similar decreasing tendency from close to the river to faraway (Fig. 5a, b). The proportion of the wetlands showed a decline with distance from the river with an increase in time (Fig. 5a),

a. The probability of wetlands presented along the elevation

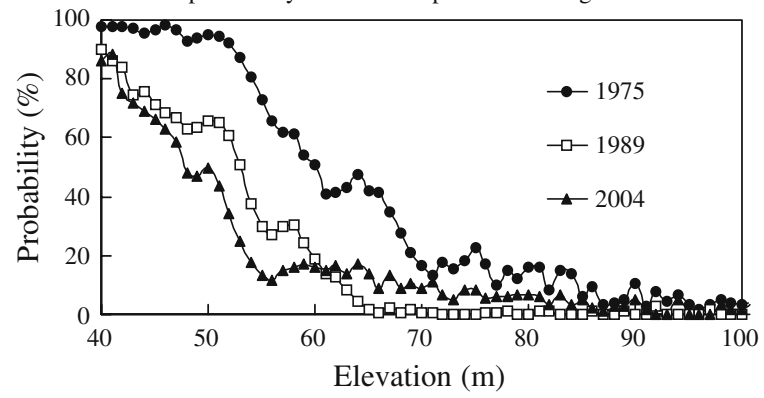

b. The proportion of wetlands distributed along the elevation

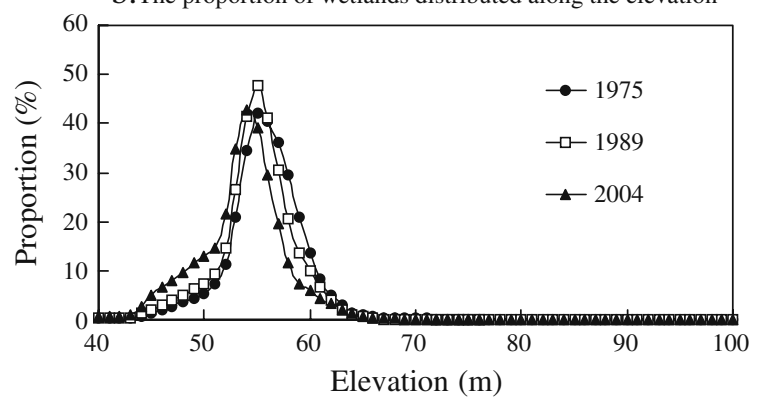

Fig. 4 Wetlands distribution along the elevation in the 3 years. a The probability of wetlands presented at an elevation of $h$ meters $=$ the wetlands area at $h$ meters/the total area at $h$ meters $\times 100 \%$; $\mathbf{b}$ the proportion of wetlands distributed at $h$ meters $=$ the wetlands area at $h$ meters/the total area of wetlands $\times 100 \%$ 

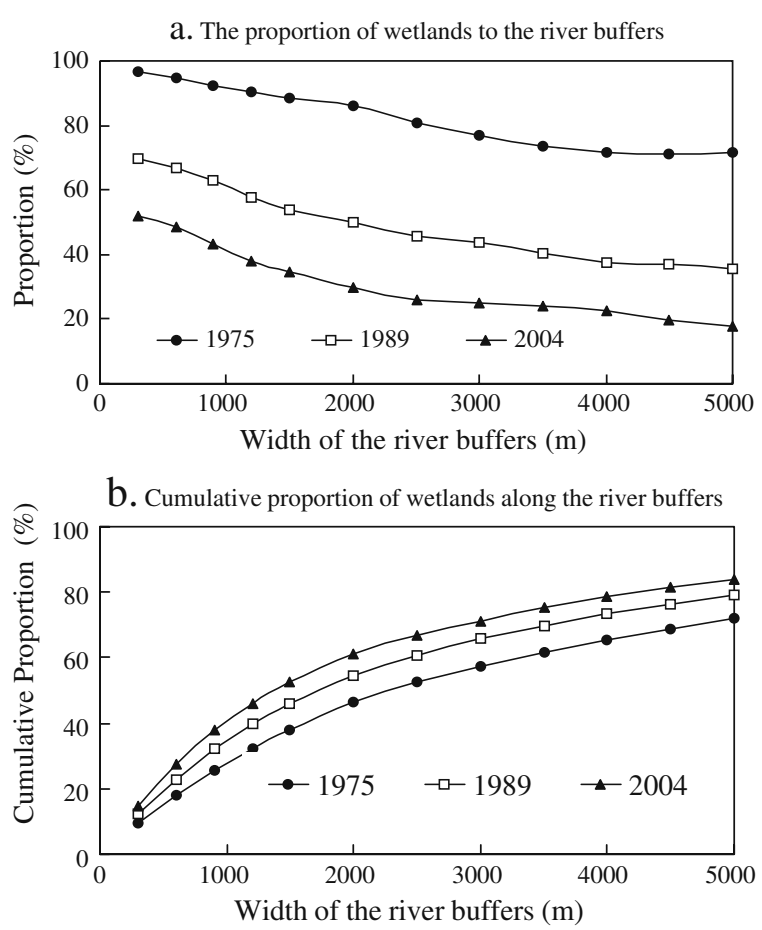

Fig. 5 Wetlands distribution in the river buffers in the 3 years. a The proportion of wetland area to the area of river buffer, $i=$ the wetlands area in the river buffer, $i /$ the total area of the river buffer, $i \times 100 \%$; b the cumulative proportion of wetlands within the river buffer, $i=$ the wetlands area in the river buffer, $i /$ the total area of wetlands $\times$ $100 \%$

which means that the loss of wetlands from 1975 through 1989 to 2004 had the similar pattern of wetland distribution in the landscape. None of the lines of the cumulative proportion of wetlands in Fig. 5b reach $100 \%$, suggesting that as much as $35 \%$ of the total wetlands area in the case of the 1975 image were beyond $5 \mathrm{~km}$ from the rivers, while it went down to $21 \%$ in 1989 and $16 \%$ in 2004 (Fig. 5b), which means wetland distribution concentrated more at a horizontal level as time went by. In 1975, the wetlands distributed more evenly in the landscape, but it changed through 1989 to 2004 with the wetlands more centralized toward the rivers. Despite the development of man-made channel networks changing the water cycle of the landscape, natural river systems and their surroundings still support much of the wetlands with a regular water regime and denser vegetation.

\section{Discussion}

Direct and indirect loss of wetlands

The loss of wetlands can be described as two ways: (1) the direct loss resulting from land use conversion and (2) the indirect loss resulting from the decline of wetland quality, especially the lack of water induced by the agricultural irrigation and channel drainage. In this region, (1) the direct impacts on the wetlands were agricultural exploitation, which altered wetlands into agricultural lands, through a series of activities, including ditching, draining, tilling, and planting and (2) the indirect impacts usually led to wetland water loss and then degraded it to grassland. The results indicated that, in period 1 , the major feature of wetland loss was the direct loss of wetland converted to farmlands, whereas, in period 2 , it was the indirect loss through degrading it to grassland. That meant that the indirect impacts on the regional wetlands increased from period 1 to period 2 and even become the major reason of wetland loss and degradation at present.

In general, conservation and restoration projects are frequently "site-specific" with little attention paid to ecological processes operating at larger scales (Kershner 1997). It is not sufficient for wetland protection though. Even without the direct impacts, wetlands would still very likely degrade from indirect impacts, such as the hydrological modification of the landscape. Thus, it is necessary to consider simultaneously the direct and indirect impacts of the human activities and environment changes at larger scales to protect the local wetlands.

Wetland distribution within the agricultural landscape context

The distribution of wetlands in the landscape was the consequence of interactional natural and human factors. The occurrence and maintenance of wetlands reflects large-scale and long-term characteristics of watersheds and regions, as well as the impact of human activities. In general, the natural factors, such as climate and terrain, determined the original landscape pattern and 
were later modified by human activity. Within a particular climatic region, geomorphology, referring to landforms and landscape relief, plays a major role in hydrology and ecology to determine an area to be wetland. Landscape position may have a significant effect on regional hydrology by controlling the type and extent of interaction with surface and groundwater flows and soil and vegetation as well. On the other hand, the function of wetlands as integral components of watersheds would vary alongside their positions in a landscape (DeBusk 1999).

Because of past land use patterns and the location of wetlands in the landscape, they are often subject to degradation and loss of function during common land conversion activities (Bedford and Preston 1988). During those years 1975-2004, approximately $67 \%$ of wetlands were lost because of agricultural land use (Figs. 2 and 3), but the pattern along the elevation and river buffer gradient were not changed much (Figs. 4 and 5), indicating that human activities affected wetlands area more than their pattern.

\section{Further studies required on wetland remnants}

According to the species-area hypothesis, larger habitats can preserve more species (Gibbs 2000). This general theory has also been proven in some wetlands; for example, in southern Illinois, USA, species richness increased significantly with wetland area or perimeter, indicating a bias toward higher assessments of quality in larger areas (Matthews et al. 2005). Yet in our study area, higher richness of wetland plants and water birds were found during the field survey in those local, small-sized wetlands. Wetlands of small areas are extremely valuable for maintaining biodiversity where the loss of small wetlands will cause a direct reduction in the connections among remaining species populations (Semlitsch and Bodie 1998).

As limited by the resolution of the Landsat TM images, the smallest unit of wetlands and land covers identified from the satellite images was determined as $0.1 \mathrm{ha}$; therefore, the existence and loss of wetlands smaller than 0.1 ha were not captured in the study. Because of their smaller areas, those wetland remnants are more likely to be influenced by human activities and climate change and ultimately converted to another land use type. Further studies are required to examine the biodiversity of those small wetland remnants and how they contribute to the integrity of the local and regional landscape.

Acknowledgements This work was supported by the National Natural Science Foundation of China (no. 40671182) and the Innovation Research Group Project supported by the National Natural Sciences Foundation of China (no. 40621061). We especially thank Dr. Kate He in Department of Biological Sciences, Murray State University, USA for providing valuable advice.

\section{References}

Balmford, A., Bruner, A., Copper, P., Costanza, R., Farber, S., Green, R. E., et al. (2002). Economic reasons for conserving wild nature. Science, 297, 950-953. doi:10.1126/science.1073947.

Bedford, B. L., \& Preston, E. M. (1988). Developing the scientific basis for assessing cumulative effects of wetland loss and degradation on landscape functions: status, perspectives, and prospects. Environmental Management, 12(5), 751-771. doi:10.1007/ BF01867550.

DeBusk, W. F. (1999). Functional role of wetlands in watersheds. A fact sheet of the Soil and Water Science Department, Florida Cooperative Extension Service, Institute of Food and Agricultural Sciences, University of Florida. Published on July 1999. Retrieved from http://edis.ifas.ufl.edu.

Elkie, P., Rempel, R., \& Carr, A. (1999). Patch analyst user's manual, TM-002 (p. 16). Thunder Bay, ON: Ontario Ministry of Natural Resource, Northwest Science and Technology.

Forman, R. T. T. (1995). Some general principles of landscape and regional ecology. Landscape Ecology, 10, 133-142. doi:10.1007/BF00133027.

Gibbs, J. P. (2000). Wetland loss and biodiversity conservation. Conservation Biology, 14(1), 314-317. doi:10.1046/j.1523-1739.2000.98608.x.

Gopal, B., \& Junk, W. J. (2001). Assessment, determinant, function and conservation of biodiversity in wetlands: Present status and future need. In B. Gopal, W. J. Junk, \& J. A. Davis (Eds.), Biodiversity in wetlands: Assessment, function and conservation (pp. 277-302). Leiden: Backhuys.

Kennish, M. J., Belton, T. J., Hauge, P., Lockwood, K., \& Ruppel, B. (1992). Polychlorinated biphenyls in estuarine and coastal marine waters of New Jersey: A review of existing pollution problems. Reviews in Aquatic Sciences, 6, 275-293.

Kershner, J. L. (1997). Setting riparian/aquatic restoration objectives within a watershed context. Restoration 
Ecology, 5, 15-24. doi:10.1111/j.1526-100X.1997. 00015.x.

Liu, H., Zhang, S., Li, Z., Lu, X., \& Yang, Q. (2004). Impacts on wetlands of large-scale land use changes by agricultural development: The Small Sanjiang Plain, China. Ambio, 6, 306-310.

Matthews, J. W., Paul, A. B., Tessene, A., Wiesbrook, S. M., \& Zercher, B. W. (2005). Effect of area and isolation on species richness and indices of floristic quality in Illinois, USA wetlands. Wetlands, 3, 607-615. doi:10. 1672/0277-5212(2005)025[0607:EOAAIO]2.0.CO;2.

Mensing, D. M., Galatowitsch, S. M., \& Tester, J. R. (1998). Anthropogenic effects on the biodiversity of riparian wetlands of a northern temperate landscape. Journal of Environmental Management, 53, 349-377. doi:10.1006/jema.1998.0215.

Mitsch, W. J., \& Gosselink, J. G. (1993). Wetlands (pp 722). New York: Van Nostrand Reinhold.

OECD/IUCN (1996). Guidelines for aid agencies for improved conservation and sustainable use of tropical and sub-tropical wetlands. Paris: OECD.

Semlitsch, R. D., \& Bodie, J. R. (1998). Are small, isolated wetlands expendable? Conservation Biology, 12(5), 1129-1133. doi:10.1046/j.1523-1739.1998.98166.x.

Spaling, H. (1995). Analyzing cumulative environmental effects of agricultural land drainage in southern Ontario, Canada. Agriculture Ecosystems \& Environment, 53, 279-292. doi:10.1016/0167-8809(94)00567-X.
State Forestry Administration China (2004). Report of the first survey of national wetland resources (in Chinese).

Turner, M. G., \& Gardner, R. H. (1991). Quantitative methods in landscape ecology. New York, USA: Springer.

Turner, M. G., Gardner, R. H., \& O’Neill, R. (2001). Landscape ecology in theory and practice: Pattern and process. New York: Springer.

Walters, D., \& Shrubsole, D. (2003). Agricultural drainage and wetland management in Ontario. Journal of Environmental Management, 69(4), 369-379. doi:10. 1016/j.jenvman.2003.09.013.

Wang, X., \& Wu, Y. (2004). Degeneration and ecological rehabilitation of wetlands in Jianghan Plain, China. Journal of Huazhong Agricultural University, 23(4), 467-471 (in Chinese).

Wang, Z., Zhang, B., Zhang, S., Li, X., Liu, D., Song, K., et al. (2006). Changes of land use and of ecosystem service values in Sanjiang Plain, Northeast China. Environmental Monitoring and Assessment, 112, 69-91. doi:10.1007/s10661-006-0312-5.

Xiao, D., \& Li, X. (2001). Landscape dynamics and sustainable land use of coastal wetlands resources in Liaohe Delta, China. Resources Science, 23(2), 31-36 (in Chinese).

Yi, G., Risley, D., Koneff, M., \& Davis, C. (1994). Development of Ohio's GIS-based wetlands inventory. Journal of Soil and Water Conservation, 49(1), 23-28. 